\title{
Unambiguous detection and improved quantification of phagotrophy in apochlorotic nanoflagellates using fluorescent microspheres and concomitant phase contrast and epifluorescence microscopy
}

\author{
Frank J. Cynar* \& John McN. Sieburth** \\ Graduate School of Oceanography, University of Rhode Island, Narragansett, Rhode Island 02882-1197, USA
}

\begin{abstract}
Recent procedures for quantifying the ingestion of non-nutritive bacterial sized particles by bacterivores lack the necessary resolution for the accurate determination of ingestion rates. Here, we describe how the filter-transfer-freeze procedure of Hewes \& Holm-Hansen (1983) permits concomitant epifluorescence and phase contrast microscopy which lets us unambiguously discriminate between ingested and non-ingested fluorescent microspheres (FM) in 4 species of apochlorotic nanoflagellates. This rapid procedure reduces the subjectivity of grazing rate determinations while improving precision. We have used this procedure to observe non-continuous feeding, egestion processes and the effect of growth inhibition on phagotrophy.
\end{abstract}

\section{INTRODUCTION}

The ecological significance of nanoflagellates as consumers of the picoplankton has been suggested by studies describing the ubiquity of picoplankton and their nanoflagellate grazers in the marine environment (Sieburth 1976, 1979, Sieburth et al. 1978, Johnson \& Sieburth 1979, 1982, Burney et al. 1981, 1982, Caron et al. 1982, Fenchel 1982c, Azam et al. 1983, Linley et al. 1983, Sherr \& Sherr 1984, Sherr et al. 1984, Davis et al. 1985). Current methods to estimate the grazing potential of nanoplankters include the use of radioisotopes (Haney 1973, Hollibaugh et al. 1980, Lessard \& Swift 1985), the correlation of the abundance of predators and prey (Sherr et al. 1984), the difference between potential and observed bacterial growth rates (Davis \& Sieburth 1984), or the comparison of prey densities with and without predators (Peterson et al. 1978, Fuhrman \& McManus 1984, Wright \& Coffin 1984).

\footnotetext{
- Present address: Institute of Marine Resources, A-008, Scripps Institute of Oceanography, University of California, La Jolla, Califormia 92093, USA

- Addressee for reprint requests
}

Several of these methods assume that bacterial growth without grazers is similar to growth with grazers, although it has been shown that bacterivorous nanoflagellates release nutrients (Burney et al. 1981, Sherr et al. 1983, Andersson et al. 1985, Goldman et al. 1985, Güde 1985, Taylor et al. 1985) and in turn nurture bacterial production (Sherr et al. 1982, Sieburth \& Davis 1982). Radioisotope techniques suffer from several limitations including artifacts arising from isotopic label leaking into the medium. Methods for estimating predation that assume predator-free filtrates after filtration through $>0.4 \mu \mathrm{m}$ Nuclepore filters (Wright \& Coffin 1984) are suspect, since such filtration permits the passage of flagellates capable of significant bacterivory (Cynar et al. 1985a). The interpretation of grazing rates obtained with any of these indirect methods, in which the fate of the prey is not observed microscopically, is burdened by several potentially faulty assumptions.

Fenchel (1980) used non-fluorescing beads to study feeding in ciliates, but found that beads $<1 \mu \mathrm{m}$ could not be resolved with phase contrast microscopy. Borsheim (1984) has recently reported on the use of fluorescent microspheres (FM) for directly observing 
the clearance rates of freshwater ciliates using epifluorescence microscopy. This ability to directly observe feeding behavior and quantify particle uptake is an improvement in quantifying phagotrophy. Although the Utermöhl settling chamber used by Børsheim (1984) is applicable to the microplankton such as ciliates, it is inappropiate for nanoflagellates (Sieburth 1979).

McManus \& Fuhrman (1986) have estimated bacterivory in nanoflagellates by enumerating ingested fluorescing paint particles (FPP) with epifluorescence microscopy in samples concentrated onto Nuclepore filters. We tried this procedure, but found it was difficult to discriminate between ingested and noningested particles. This prompted us to combine the filter-transfer-freeze (FTF) procedure of Hewes \& Holm-Hansen (1983) with the use of bacterial-sized fluorescent microspheres to permit the concomitant use of epifluorescence and phase contrast microscopy to directly and unambiguously detect and quantify ingested bacterial sized particles. Here we use this procedure to directly study the processes involved in nanoflagellate phagotrophy.

\section{MATERIALS AND METHODS}

Nanoflagellate predators. All 4 apochlorotic nanoflagellates fall in the 2 to $8 \mu \mathrm{m}$ size range. Three of the flagellates were isolated from Narragansett Bay by Davis \& Sieburth (unpubl.), and include the kinetoplastids Pseudobodo tremulans (Greissmann 1914; ATTC 50061), Monas gracilis nom. prov., and the cryptomonad Cyathomonas sp. (previously referred to as Bodo sp.; Davis 1982, Davis \& Sieburth 1984; ATTC 50108). An aloricate choanoflagellate in the genus Codosiga (James-Clark 1868) was obtained from B.S.C. Leadbeater, University of Birmingham, England. The flagellates were grown in $500 \mathrm{ml}$ polycarbonate flasks containing autoclaved seawater with 1 to 4 sterile rice grains added for enrichment of the indigenous bacterial prey. Observations of flagellate morphology and motility were made with a Zeiss IM-35 inverted phase contrast and epifluorescence microscope at $400 \times$. Flagellate volumes were determined from length (L) and width (W) measurements taken from micrographs made of the experimental populations and calculated as $(4 \pi / 3)(\mathrm{L} / 2)^{2}(\mathrm{~W} / 2)$ from Hodgman et al. (1962).

Prey-sized fluorescent particles. The trialdehyde resin-based fluorescent paint particles (FPP) (Radiant Color Co., Richmond, California, USA) as used by McManus \& Fuhrman (1986) have no defined size range, and have been size fractionated before use in order to mimic the size spectrum of bacteria. Wet filtration of the FPP passing through a $1 \mu \mathrm{m}$ Nuclepore filter and collected onto a $0.4 \mu \mathrm{m}$ Nuclepore filter were sized using image analysis (Sieracki et al. 1985) at $1500 \times$ magnification.

Fluorescent carboxylated microspheres (Fluoresbrite, Polysciences Inc., Warrington, Pennsylvania, USA) are available in an assortment of diameters spanning those of natural bacteria. We used $0.57 \mu \mathrm{m}$ diameter spheres of yellowish-green fluorescence $(458 \mathrm{~nm}$ excitation maximum, $540 \mathrm{~nm}$ emission maximum). The microspheres were suspended in $3 \%$ bovine serum albumin (BSA w/v final concentration) in an attempt to adsorb protein and simulate the proteinaceous membranes of natural prey. The quantity of protein covalently bonde to the FM was not determined. Image analysis was also used to size the FM as described above.

Sample preparation and microscopic examination. The enumeration method of Davis \& Sieburth (1982) was originally attempted in which cultures of nanoflagellates with and without FM were stained with acridine orange, concentrated on $1.0 \mu \mathrm{m}$ Nuclepore filters, and examined with only epifluorescence microscopy since the translucent Nuclepore filter precludes phase contrast microscopy. We then transferred the filter-concentrates of the predator-prey suspensions from the membrane filter to a glass slide by freezing (Hewes \& Holm-Hansen 1983) to allow the use of both phase contrast and epifluorescence microscopy on the same preparation. Five to $10 \mathrm{ml}$ of preserved sample was filtered onto the shiny side of a 1 to $2 \mu \mathrm{m}$ Nuclepore membrane by gentle vacuum $(<8 \mathrm{~cm}$ $\mathrm{Hg}$ ) until only a film remained, but not to dryness. The filter was placed on a clean glass slide containing a uniform condensation of water droplets obtained by breathing on a cold slide. The glass slide with filter was immediately placed on a $2 \mathrm{~kg}$ block of aluminum at $-5^{\circ} \mathrm{C}$. While the preparation is completely frozen, the membrane filter is peeled off to ensure a good transfer of the cell concentrate. After thawing, a coverslip is placed directly on the slide while avoiding the trapping of air bubbles, and the edges are sealed with paraffin to reduce drying during storage. These slide preparations were examined with concomitant phase contrast and epifluorescence microscopy (UV or blue excitation) using an Olympus BHT-F epifluorescence microscope at $1250 \times$ magnification.

Influence of the growth inhibitor cycloheximide on predation. Cyathomonas sp. grown in nce grain enrichment culture was divided into 2 treatments (with 2 replicates each) plus a control. Cycloheximide, an inhibitor of protein synthesis in eucaryotes (Morris 1966), was added to 2 of the treatments at $0.1 \mathrm{~g} \mathrm{l}^{-1}$ and $1 \mathrm{~g} \mathrm{I}^{-1}$, which are $1 \times$ and $10 \times$ the concentration used by Newell et al. (1983). Sterile pairs of replicate flasks 
containing BSA coated FM $\left(1 \times 10^{7} \mathrm{ml}^{-1}\right.$ final concentration) were inoculated at $1 \mathrm{~h}$ intervals for $4 \mathrm{~h}$ with xenic nanoflagellate cultures of each treatment and were examined directly with concomitant phase contrast and epifluorescence illumination on a Zeiss IM-35 inverted photomicroscope at $400 \times$ magnification. Portions of the replicate treatments were removed and fixed with glutaraldehyde $(1 \% \mathrm{v} / \mathrm{v})$ at the end of hourly incubation periods for $4 \mathrm{~h}$. Samples were prepared and examined as above, and the presence or absence of ingested spheres was determined for 300 to 500 flagellates per replicate using microcomputerbased plankton counting software (Cynar et al. 1985b).

Predation experiments. Flagellate enrichments of Pseudobodo tremulans, Monas gracilis, and Codosiga $\mathrm{sp}$. were grown in the dark on a rotary shaker (140 rpm) at ambient temperature $\left(20\right.$ to $\left.25^{\circ} \mathrm{C}\right)$. Forty-eight h old flagellate cultures grown on rice grains were filtered through $8 \mu \mathrm{m}$ Nuclepore filters without vacuum to remove bacterial aggregates and then transferred to sterile $1 \mathrm{l}$ teflon bottles. Replicate $1 \mathrm{ml}$ aliquots of the $<8 \mu \mathrm{m}$ filtrate were removed prior to the experiment, fixed ( $2 \%$ glutaraldehyde $v / v)$, stained with DAPI at $10 \mu \mathrm{g} \mathrm{ml}^{-1}$ final concentration (Porter \& Feig 1980), and examined on $0.2 \mu \mathrm{m}$ Irgalan black stained Nuclepore filters (Watson et al. 1977) to determine bacterial concentrations. Specific volumes of a suspension of BSA treated $0.57 \mu \mathrm{m}$ FM were pipetted into a known volume of each nanoflagellate culture in teflon bottles, so that the concentrations of FM and cultured bacteria were made approximately equivalent. At the end of 5 , 10,20 , and $40 \mathrm{~min}, 10 \mathrm{ml}$ portions were removed from each bottle and fixed as above, and prepared and examined as described above. An average of 360 flagellates per preparation were examined in order to determine the number of ingested FM as described above.

Calculation of predation parameters. The frequency of predators with $0,1,2, \ldots 8 \mathrm{FM}$ was converted to percentages and a mean ingestion rate (no. FM ind ${ }^{-1}$ time $^{-1}$ ) was calculated for each species for each of the 4 sampling periods. The grazing rate, which is expressed as no. bacterial-sized particles (BSP) ingested ind $^{-1} \mathrm{~h}^{-1}$, is calculated from the ingestion rate as grazing rate $=\left(\right.$ no. ingested $F M$ ind $\left.d^{-1} \min ^{-1}\right)\left(60 \operatorname{min~h}^{-1}\right)$ (no. BSP no. FM ${ }^{-1}$ ), where the FM constitute $50 \%$ of the BSP (FM + bacteria) present. This calculation assumes that the probability of a flagellate encountering an FM or bacterium is essentially equal and constant over the $40 \mathrm{~min}$ sampling period. The Poisson distribution of FM uptake was computed at each incubation interval (Snedecor \& Cochran 1980). The maximum clearance rate or volume of water a flagellate cleared of bacterial-sized particles per unit time $\left(\mathrm{nl} \mathrm{h} \mathrm{h}^{-1}\right)$ and predator cell volumes cleared per hour $\left(\mathrm{h}^{-1}\right)$ was calculated as in Fenchel (1980). A few of the commonly used terms have been abbreviated in this paper in order to avoid redundancy and are summarized here for easy reference: FPP, fluorescent paint particles; FM, fluorescent microspheres; FTF, filtertransfer-freeze; BSP, bacteria sized particles; BSA, bovine serum albumin.

\section{RESULTS}

\section{Comparison of bacterial-sized particles and enumeration procedures}

The size distribution of bacteria from nanoflagellate enrichments, fluorescent paint particles (FPP), and fluorescent microspheres (FM) are compared in Fig. 1. The mode of the size distribution $(n=405)$ of the DAPI stained bacterial cultures is at $0.59 \mu \mathrm{m}$, with $55 \%$ of the cells occurring between 0.4 and $0.7 \mu \mathrm{m}$. The mode of the size distribution of the $0.57 \mu \mathrm{m} \mathrm{FM}(n=158)$ is

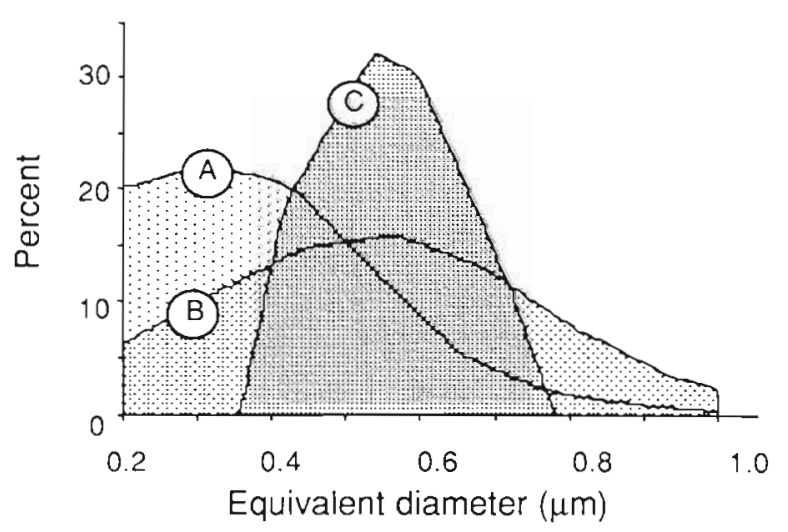

Fig. 1. A comparison of the size distributions of (A) fluorescent paint particles, (B) fluorochrome stained bacteria, (C) $0.57 \mu \mathrm{m}$ fluorescent microspheres

at $0.57 \mu \mathrm{m}$ with $90 \%$ occurring in the 0.4 to $0.7 \mu \mathrm{m}$ diameter range. The mode of the size distribution $(\mathrm{n}=$ 901) of the FPP is at $0.3 \mu \mathrm{m}$, with $42 \%$ occurring between 0.4 and $0.7 \mu \mathrm{m}$.

Cultures of the cryptomonad Cyathomonas sp. were prepared according to the usual and the new procedure and photomicrographed with combinations of epifluorescence and phase contrast microscopy in order to illustrate the ability to discriminate between ingested and non-ingested FM using these 2 procedures (Fig. 2). Fig. 2A,B illustrate the difficulty of visualizing Nuclepore membrane filter preparations while the ability of the FTF procedure to detect the position of FM with phase contrast microscopy (Fig. 2C) and concomitant epifluorescence microscopy (Fig. $2 \mathrm{D}, \mathrm{E})$ illustrate the latter procedure's versatility. 
Influence of the growth inhibitor cycloheximide on predation

Ingested spheres were detected in both untreated and cycloheximide treated nanoflagellate cultures. Mean ingestion rates over $4 \mathrm{~h}$ in the presence of 0.1 and $1.0 \mathrm{~g}$ cycloheximide $\mathrm{l}^{-1}$ were reduced to 40 and $22 \%$ that of the control population (Fig. 3). This would indicate that cycloheximide inhibits grazing in the flagellates during $4 \mathrm{~h}$ of treatment, but that inhibition is not complete.

\section{Ingestion rate estimates}

The initial bacterial concentrations in the experimental flasks were estimated at $3.9,6.7$, and $18.3 \times 10^{6}$ bacteria $\mathrm{ml}^{-1}$ for cultures of Monas gracilis, Pseudobodo tremulans, and Codosiga sp., respectively. Clumping of bacteria was observed in the $M$. gracilis enrichment cultures.

Ingestion of FM could be discerned without ambiguity in each flagellate species. The percentage of each flagellate population with a given number of ingested FM (Fig. 4) follows the expected Poisson distribution after $5 \mathrm{~min}$, indicating that the initial FM uptake follows the response predicted for organisms ingesting prey with equal probabilities. This relation breaks down, however, after 20 min (Fig. 4). Individuals with 3 to 6 ingested FM after the first 5 min of incubation comprised 2 to $7 \%$ of each population, corresponding to grazing rates of 72 to $144 \mathrm{BSP}$
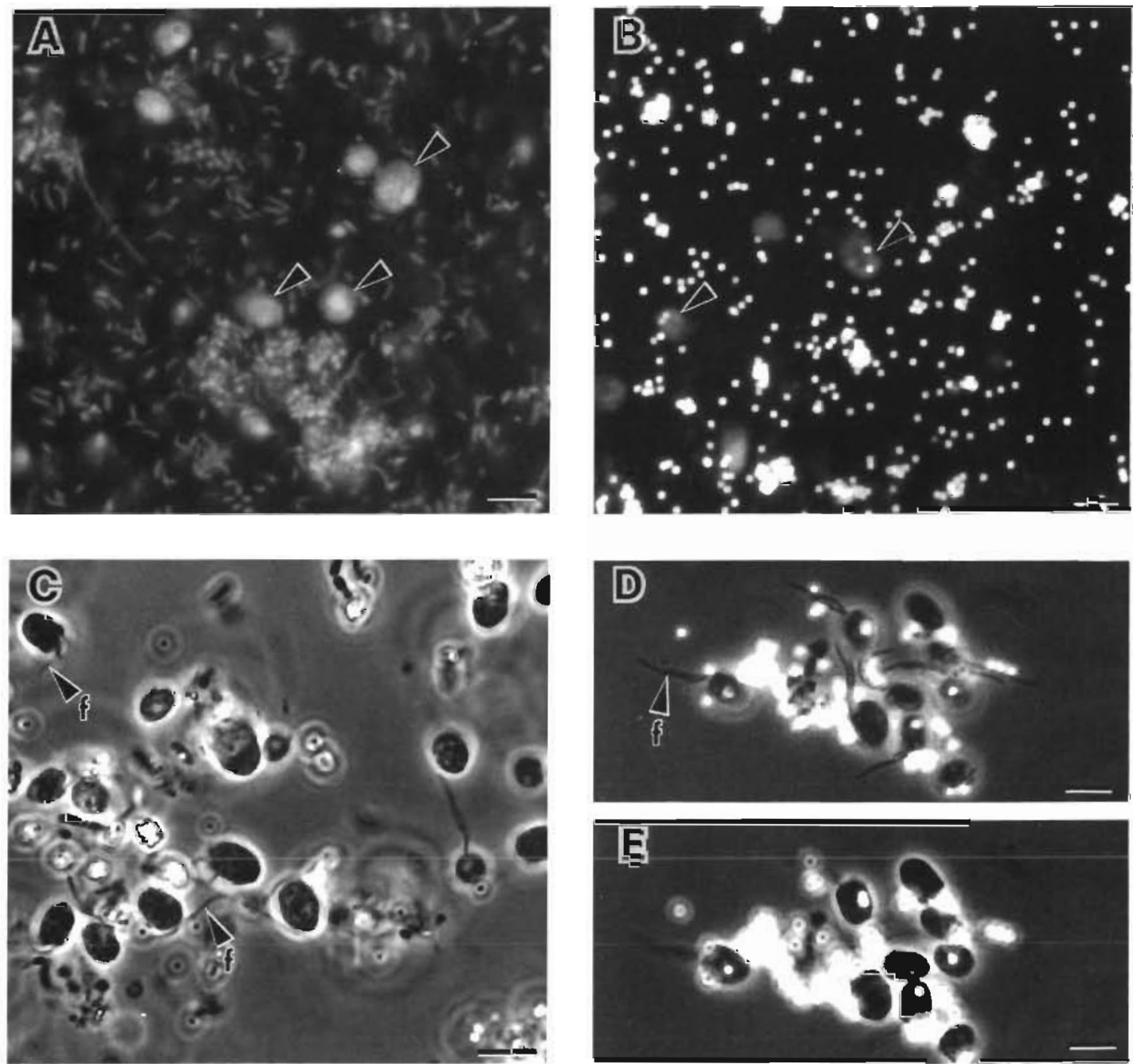

Fig. 2. Micrographs comparing images produced with various procedures and microscopies used to detect microsphere uptake in the cryptomonad Cyathomonas sp. (A) Acridine-orange stained flagellates on a membrane filter illuminated by blue light using epifluorescence microscopy; (B) similar preparation of flagellates incubated with microspheres; (C) a filter-transfer-freeze preparation of flagellates incubated with spheres and examined with phase contrast microscopy; (D) the same preparation viewed with concomitant phase contrast and epifluorescence mucroscopy, showing non-ingested spheres adjacent to the flagellates; $(E)$ ingested spheres when the focal plane bisects the flagellates. All bars $=5 \mu m_{i} f=f l a g e l l u m$; arrows in $(A)$ and (B) point to nanoflagellate cells; arrows in (C) and (D) point to protistan flagella 


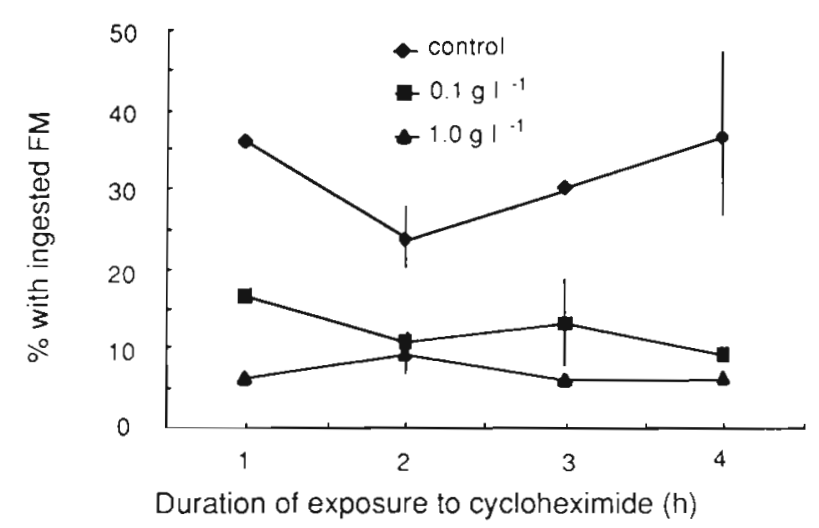

Fig. 3. Effect of cycloheximide on the inhibition of sphere ingestion in Cyathomonas sp. Vertical bars denote range of replicates when values deviate from the mean by more than $7 \%$

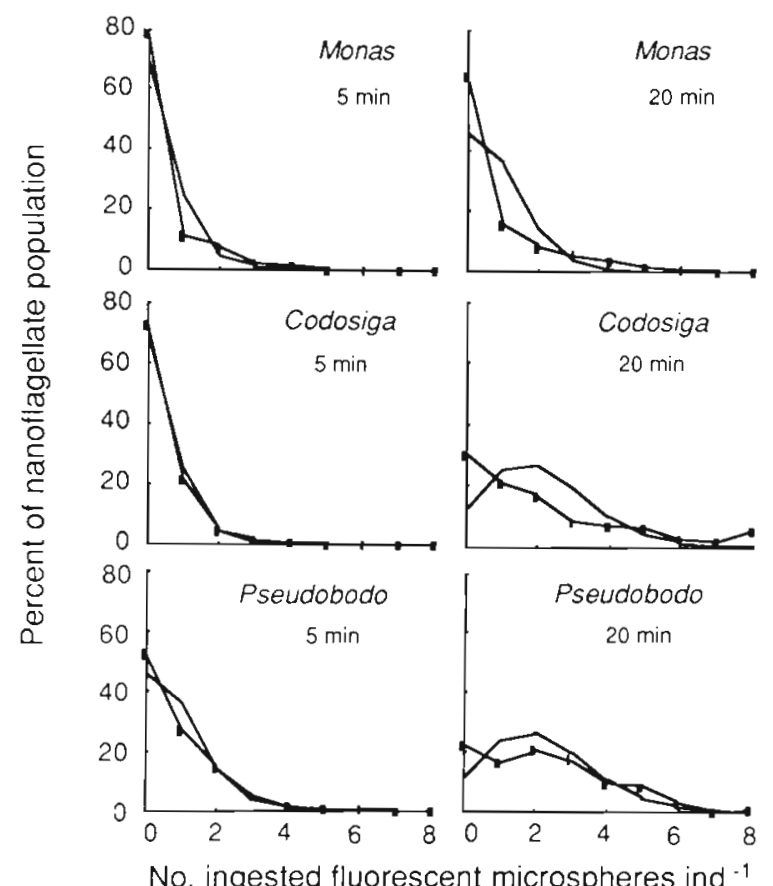

Fig. 4. Influence of incubation time on the percent of populations with a given number of ingested spheres as shown by the 5 and $20 \mathrm{~min}$ time series histograms ( $\mathbf{m})$. The expected Poisson distributions are also plotted (-)

ind $\mathrm{d}^{-1} \mathrm{~h}^{-1}$. However, 52 to $79 \%$ of the predators had not ingested FM after $5 \mathrm{~min}$ and this percentage was reduced to 15 to $18 \%$ after $40 \mathrm{~min}$ for Pseudobodo tremulans and Codosiga sp. $65 \%$ were non-feeding cells after $20 \mathrm{~min}$ for Monas gracilis (Fig. 5A). The change in the percent of each population with 1 or more ingested microspheres as a function of time is curvilinear.

The effect of incubation time on the mean number of ingested $F M$ ind ${ }^{-1}$ is illustrated in Fig. 5B. The response of each species is unique, with 0.4 to $0.8 \mathrm{FM}$

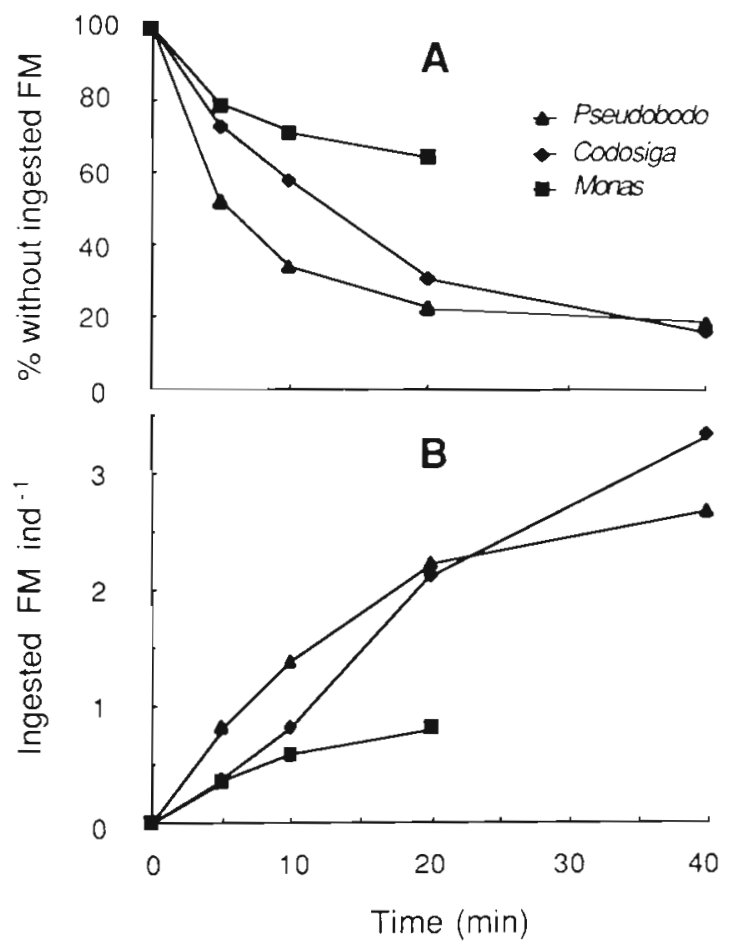

Fig. 5. Effect of incubation time on the ingestion of fluorescent microspheres showing (A) percent of each flagellate population without ingested $F M_{\text {; }}(B)$ the mean number of ingested $\mathrm{FM}_{\text {ind }}^{-1}$

ind $^{-1}$ observed after $5 \mathrm{~min}$ and 2.7 to $3.4 \mathrm{FM}$ ind $^{-1}$ recorded after $40 \mathrm{~min}$. Microsphere ingestion by the Monas gracilis and Pseudobodo tremulans populations appears to begin to level off after $10 \mathrm{~min}$ of incubation, while the Codosiga sp. populations show no indication of this.

\section{DISCUSSION}

\section{Comparison of procedures for quantifying phagotrophy}

This study was originally concerned with the use of inert particles to study the early stages of phagotrophy of BSP by various species of nanoflagellates. Neither FPP nor FM mimic the exact size distribution of the indigenous bacteria enriched by rice grain, upon which the nanoflagellates are cultured (Fig. 1). The spherical fluorescent particles also do not mimic the shapes of natural bacteria. The FPP distribution is skewed to the smaller, $<0.4 \mu \mathrm{m}$ fraction, presumably due to the tendency for the trialdehyde resin to aggregate. By contrast, FM with a nominal diameter of $0.57 \mu \mathrm{m}$ had a tight distribution around the mean size of the bacterial prey and were therefore used in this study. Fluorescent microspheres of defined size proved superior both to the FPP which rapidly clump and 
necessitate considerable preparation before use and to the use of stained bacteria that fluoresce dimly and fade quickly. No acute toxic effects of the FM have been observed in nanoflagellate cultures, even after several weeks of incubation. Although the wide size spectrum of the FPP may make them preferable as qualitative tracers of ingestion, the FPP might pose a problem in calculating grazing rates if only a subset of the size-spectrum is perceived as prey by the predators, but more importantly, the procedure of filterfractionating particles, checking the size distribution, and having to discriminate between large particles and clumps of smaller particles was found to be timeconsuming and unsatisfactory. The use of suitable diameter commercially available FMs proved highly satisfactory by comparison.

Although fluorochrome-stained preparations were adequate to estimate populations of the flagellate Cyathomonas sp., and their associated bacterial enrichments concentrated onto Nuclepore filters (Fig. 2A), Cyathomonas cultures incubated with FM, stained with acridine orange, collected onto Nuclepore filters and observed only with epifluorescence illumination in the usual manner (Fig. 2B) did not allow the unambiguous determination of sphere ingestion. Initial estimates of FM ingestion using just epifluorescence microscopy were highly variable and could not be determined without substantial subjectivity.

Cell morphology, flagella and other structures, can be observed with phase contrast microscopy (Fig. 2C), while concomitant illumination with blue or UV light shows all fluorescing microspheres (Fig. 2D,E) in context with the predator cells. The important difference between the usual procedures and the one developed here is the ability to focus through a preparation and distinguish between non-ingested spheres (those that appear in a different plane of focus from the flagellates, Fig. 2D) and ingested spheres (those that are in the same plane of focus as the flagellates: Fig. 2E). The ability to adjust the brightness of the predators with white light and the brightness of the fluorescing spheres with blue or UV light sources enables the microscopist to optimize the contrast between flagellates and artificial BSP. We found that for both FPP and FM, the use of epifluorescence microscopy alone did not provide optimal illumination for either the predators or the BSP. Although the FTF technique is only semi-quantitative (Hewes \& Holm-Hansen 1983), this should not seriously affect the quantification of the relative proportion of predators with and without ingested spheres. Our procedure eliminates the ambiguity in the discrimination between ingested and noningested BSP reported by McManus \& Fuhrman (1986). Also, examination of FTF preparations with negative phase contrast (anoptral) or Nomarski optics renders light images against a dark background that enable one to discriminate cellular structures. Concomitant use of these transmitted light microscopies with epifluorescent microscopy may also be used to observe and detect the orientation of ingested FM, autofluorescent, and fluorescent-stained prey or plastids.

\section{Ingestion during growth inhibition}

Nanoflagellate phagotrophy was reduced in the presence of the eucaryote inhibitor cycloheximide, but was not completely blocked, as shown in Fig. 3. The nanoflagellate cultures were in a post-exponential growth stage and would be expected to be synthesizing RNA (the target of cycloheximide inhibition) more slowly. It is a well-known phenomenon that inhibitors can only inhibit actively metabolizing cells, therefore the observation of the incomplete blockage of FM ingestion in senescent populations is expected. We have observed similar responses of incomplete blockage of FM ingestion with cycloheximide in species of Pseudobodo, Bodo, and Monas (unpubl. data). The process of cell division may also be responsible in part for the insensitivity of cells to inhibitors. Studies using synchronous cultures of the ciliate Tetrahymena pyriformis suggest that the uptake of nutrients (Hamburger 1965) and the inhibitor actinomycin (Nachtwey \& Dickinson 1967) are delayed if added during the period of cell division. Bacterivory or bacterial production estimates using cycloheximide inhibition (Fuhrman \& McManus 1984) must be interpreted cautiously (Newell et al. 1983, Sanders \& Porter in press), until a better understanding of the cell processes mediating phagotrophy and the assimilation of eucaryote inhibitors is obtained.

\section{Ingestion rates}

Predation rates for all 3 flagellates ranged from 0 to $144 \mathrm{BSP}$ ind $\mathrm{d}^{-1} \mathrm{~h}^{-1}$, with maximum population clearance rates of $1.0,1.2$ and $0.4 \mathrm{nl} \mathrm{h}^{-1}$ for Monas gracilis,

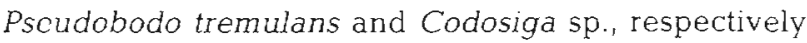
(Table 1). Species differences such as cell volume or feeding behavior may be important.

Feeding behavior may be responsible for the low ingestion rates observed here and by others (Daggett \& Nerad 1982, McManus \& Fuhrman 1986). The predators chosen for this study vary in body volume; $13 \pm$ $6,28 \pm 11,33 \pm 11$, and $155 \pm 57 \mu^{3}$ (mean $\pm 1 \mathrm{SD}$ ) for Pseudobodo tremulans, Monas gracilis, Cyathomonas sp., and Codosiga sp., respectively. Prey clearance is inversely related to predator cell volume, increasing with decreasing predator volume (Table 1). A special stalk or pedicel for attachment has been 
Table 1. Predator and predation parameters determined from the uptake of $0.57 \mu \mathrm{m}$ fluorescent microspheres for 3 different sized bacterivorous nanoflagellates. Obs.: observed rate; adj.: rate adjusted for potential egestion

\begin{tabular}{|c|c|c|c|c|c|c|c|c|c|}
\hline \multirow[t]{2}{*}{ Species } & \multicolumn{2}{|c|}{ Size $(\mu \mathrm{m})$} & \multirow{2}{*}{$\begin{array}{l}\text { Volume } \\
\left(\mu \mathrm{m}^{3}\right)\end{array}$} & \multicolumn{2}{|c|}{$\begin{array}{l}\text { Max. ingestion } \\
\left(\mathrm{FM} \text { ind } \mathrm{d}^{-1} \mathrm{~h}^{-1}\right)\end{array}$} & \multicolumn{4}{|c|}{ Max clearance } \\
\hline & $\mathrm{L}$ & $W$ & & obs. & (adj.) & obs. & (adj.) & obs. & (adj.) \\
\hline Pseudobodo sp. & 3.2 & 2.4 & 13 & 8.3 & $(10.8)$ & 1.2 & $(1.6)$ & 9.2 & (12) \\
\hline Monas gracilis & 3.4 & 4.0 & 28 & 3.8 & $(5.0)$ & 1.0 & $(1.3)$ & 3.5 & $(4.6)$ \\
\hline Codosiga sp. & 7.4 & 5.4 & 155 & 7.0 & $(10.4)$ & 0.4 & $(0.6)$ & 0.3 & $(0.4)$ \\
\hline
\end{tabular}

indicated for $M$. gracilis and Codosiga (Leadbeater 1985). All of the species used in this study have been observed to feed after attachment to the culture flask, which permits a feeding current to be created by flagellar oscillations. This 'filtering' type of behavior differs from the 'encounter' feeding behavior of various Bodonid flagellates (Davis 1982, Davis \& Sieburth 1984). Lighthill (1976) and Fenchel (1982a) present the view that small grazers would do better if attached to a surface where they could create feeding currents and draw water around them, than if they were free cells which would have to move through a parcel of water to encounter prey. Since these flagellates were isolated from open waters they are usually thought of as freeswimmers. A large fraction of the cultures, however, tend to attach to the surfaces of the container. Davis (1982) observed that strains of flagellates that do not attach to surfaces are rare. Attached predators pose problems for the accurate enumeration of bottled populations. The use of methods which do not take the attachment of flagellates into account will over-estimate grazing, since the attached predators may not be detected while still consuming unattached prey. Our precautions taken while determining ingestion specifically eliminated aggregated particles and prevented the flagellates from attaching to the container wall. These free-swimming experimental populations were made to simulate the non-attached members of natural populations which feed on free cells, and may represent our conception of how pelagic populations occur rather than the way they exist in nature. Caron et al. (1982) found that nanoplankton abundances on marine snow were, on average, 23 times higher than in the surrounding bulkwater. The importance of microparticulates as sites of enhanced microbial activity has been reported by Silver et al. (1978), Caron et al. (1982), and Goldman (1984a). Therefore it is likely that particle-associated prey are grazed more rapidly than the free 'prey' used in this study. Goldman (1984a) has suggested that nanoflagellates are always associated with particle surfaces, and comments that current procedures have made it impossible to accurately estimate differences between free-swimming and particlebound predators (Goldman 1984b).
Our clearance estimates of 0.4 to $1.2 \mathrm{nl} \mathrm{h}^{-1}$ (Table 1) are low compared to Davis \& Sieburth's (1984) estimates made with $>4 \times 10^{6}$ bacteria $\mathrm{ml}^{-1}$ in which mean rates of 15 to $39 \mathrm{nl} \mathrm{h}^{-1}$ were obtained for estuarine nanoflagellates. Daggett \& Nerad (1982) estimated the grazing rates of a fast growing, continuously feeding, Bodonid flagellate as 25 bacteria ind ${ }^{-1} h^{-1}$, which is only slightly greater than our 8 to $17 \mathrm{BSP}$ ind $^{-1} \mathrm{~h}^{-1}$ estimates. Fenchel (1982b) reported clearance rates of 1.4 to $79 \mathrm{nl} \mathrm{h}^{-1}$ for similarly sized nanoflagellates. When clearance is expressed in units of predator cell volume swept clear per unit time, our rate of $0.92 \times 10^{5} \mathrm{~h}^{-1}$ for Pseudobodo tremulans (Table 1) is within $10 \%$ of Fenchel's (1982b) estimate of $1.1 \times 10^{5}$ $\mathrm{h}^{-1}$ for the same species. Similarly, our clearance rate for Monas gracilis $\left(1.0 \mathrm{nl} \mathrm{h}^{-1}\right)$ is within the range of rates $\left(0.2\right.$ to $\left.1.0 \mathrm{nl} \mathrm{h}^{-1}\right)$ observed by Sherr et al. (1983) for a similarly sized isolate of the same genus. Using FPP with analogous methods, McManus \& Fuhrman (1986) reported a low clearance rate of $0.6 \mathrm{nl} \mathrm{h}^{-1}$ for a coastal isolate of an apochlorotic chrysomonad. Whether the differences in the various values of grazing rates reported in the literature are due to the inclusion of populations associated with the surfaces of particles and flasks in addition to the free cells or is due to the indigestibility of artificial particles remains to be investigated. It is not known if flagellates can use sensory transduction to discriminate between natural prey and non-nutritive particles, although Mueller et al. (1965), Dubonsky (1974), and Fenchel (1980) have reported no indication for this. However, Sibbald \& Albright (1986) have recently reported a positive chemosensory response of Pseudobodo sp. to its bacterial prey, and Pace (1986) has warned that FM may provide accurate grazing rates for specific species of cultured nanoflagellates, but natural community grazing rates may be inaccurate because some species may discriminate against FM.

If all the individuals of a predator population were feeding, then one would expect a linear relation between the percent of the population with 1 or more ingested FM and the duration of incubation with FM. The non-linearity of this relation for each species studied ( $\%$ without FM in Fig. 5A) suggests that the 
populations contain both feeding and non-feeding individuals. The curve of FM uptake after $5 \mathrm{~min}$ follows the Poisson distribution; however a comparison of the observed and computed FM uptake distributions after 20 min incubation illustrates that the frequency of predators with no ingested FM is higher than would be expected from the Poisson distribution (Fig. 4). Noncontinuous feeding may be indicated by a deviation from the Poisson distribution. Processes of cell division may be responsible in part for the non-continuous ingestion of particles as suggested by studies with ciliates. Chapman-Anderssen \& Nilsson (1968) have reported that synchronous cultures of the ciliate Tetrahymena pyriformis did not ingest inert carmin particles if added during the interval of cell division. Studies of the influence of cell processes on nanoflagellate phagotrophy have just been started, but preliminary observations by Dag Klaveness (unpubl.) indicate that non-continuous feeding seriously affects the measurement of grazing rates on natural bacteria in the cryptomonad Cyathomonas. In the present study, batch cultures of flagellates grown in the dark are most probably asynchronous, thus resulting in a timeaveraging of division events over the cell cycle. Our observation of a significant occurrence of non-phagotrophic flagellates may be explained by intermittent mitotic activities of asynchronous populations.

Prey egestion may also be responsible in part for the observed patterns and rates of FM ingestion; however, egestion of FM has not been observed directly. Differences in flagellate size may control the rate of formation of digestive vacuoles and therefore the maximum number of ingested FM. Six or more FM ingested after 40 min were observed in $22 \%$ of the Codosiga sp. population which has a 5 to $7 \mu \mathrm{m}$ diameter, while this value is $8 \%$ in the Pseudobodo tremulans population with a 2 to $3 \mu \mathrm{m}$ diameter. Such differences may also be attributable in part to species-specific egestion rates. The presence of stringy clumps of bacteria in the Monas gracilis enrichment culture may have resulted in the lower bacterial abundance observed. If the bacteria were initially underestimated and an equivalent amount of FM were added, then the bacteria would outnumber the FM and ultimately affect the grazing estimate for this species.

An examination of the non-linear relation of FM uptake over time (Fig. 5B) indicates that egestion may be quite important. A similar trend is illustrated in Fig. 4, where the observed distribution of FM uptake in the Pseudobodo tremulans and Codosiga sp. populations after 5 min parallels the computed Poisson curve; however after $20 \mathrm{~min}$ the agreement between the observed and computed distributions is weak. Estimates of grazing rates for Monas gracilis and Pseudobodo are generally higher initially and decline after $5 \mathrm{~min}$, while Codosiga attained a maximum ingestion rate at $10 \mathrm{~min}$ and declined thereafter. These trends may reflect the effect of a maximum rate of food vacuole formation or the effect of egestion of FM after as few as 5 min for $M$. gracilis and Pseudobodo and 10 min for Codosiga. McManus \& Fuhrman (1986) have also suggested that nanoflagellates are egesting FPP (Fig. $2 \& 3$ ). We assumed that the deviation from nonlinear ingestion is due to egestion processes, and that it can be represented as a linear function of time.

Egestion was estimated as the difference between the maximum ingestion rate and the observed ingestion rates. Maximum ingestion rates were calculated from the slope of a line tangent at each point on the curves in Fig. 5B. The residual differences between the maximum predicted and observed ingestion values were fitted to a linear regression and the slopes were interpreted as estimates of egestion. Egestion was estimated as 2.1, 4.2, and 5.3 FM ind ${ }^{-1} \mathrm{~h}^{-1}$ for Monas gracilis, Pseudobodo tremulans, and Codosiga sp. respectively, suggesting that ingestion and egestion processes are of a similar magnitude. Plots of the predicted values generated by the regression equations are in close agreement with the observed values for each species. An examination of the time series of flagellate ingestion curves indicated that egestion may be important after $5 \mathrm{~min}$ of incubation for $M$. gracilis and $P$. tremulans and after $20 \mathrm{~min}$ for Codosiga. Ingestion rates adjusted for egestion were obtained by adding the estimated egestion and observed ingestion rate estimates. Adjusted ingestion rates at 5 min were 10.8 and $5 \mathrm{FM}$ ind ${ }^{-1} \mathrm{~h}^{-1}$ for $P$. tremulans and $M$. gracilis and 10.4 FM ind ${ }^{-1} \mathrm{~h}^{-1}$ for Codosiga after $20 \mathrm{~min}$, corresponding to gross clearance rates of 1.6, 1.3, and $0.6 \mathrm{nl} \mathrm{h}^{-1}$ (Table 1), respectively.

\section{CONCLUSIONS}

Over the past few years, studies estimating the grazing rates of bacterivorous flagellates reported rates that vary by an order of magnitude (Daggett \& Nerad 1982, Fenchel 1982b, Sherr et al. 1983, Davis \& Sieburth 1984). Most of these studies used indirect methods which do not permit the detection or quantification of processes affecting phagotrophy.

Our dissatisfaction with the current procedures prompted our use of the FTF procedure for the rapid and non-complicated detection of FM ingestion. The additional resolution provided by the concomitant use of phase contrast and epifluorescence microscopy is crucial for the precise determination of ingestion of small $<10 \mu \mathrm{m}$ protists. Fluorescent microspheres used with the FTF procedure enabled us to detect and quantify the effect of cycloheximide on phagotrophy in the 
cryptomonad Cyathomonas sp. Our grazing rate estimates, although limited to only 3 species of widely occurring nanoflagellates, do illustrate the influences of size, non-continuous feeding, and egestion on flagellate phagotrophy. The use of FM as tracers of phagotrophy on a per cell basis has enabled the study of cellular processes affecting the transfer of energy between the 2 smallest trophic entities, those in the picoplankton and nanoplankton size fractions. Our procedure for the unambiguous detection of phagotrophy in nanoplankters has the potential to allow the direct investigation of the cellular mechanisms of flagellate phagotrophy and their chemosensory behavior.

Acknowledgements. The authors thank Paul W. Johnson and Paul G. Davis for critically reviewing an earlier version of the manuscript. Barry Leadbeater is acknowledged for the aloricate choanoflagellate, a species of Codosiga. This work was supported in part by the Biological Oceanography Program of the National Science Foundation through grant OCE8511365 .

\section{LITERATURE CITED}

Andersson, A., Lee, C., Azam, F., Hagström, Å. (1985). Release of aminoacids and inorganic nutrients by heterotrophic marine microflagellates. Mar Ecol. Prog. Ser 23: 99-106

Azam, F., Fenchel, T., Field, J. G., Gray, J. S., Meyer-Reil, L. A., Thingstad, F. (1983). The ecological role of watercolumn microbes in the sea. Mar. Ecol. Prog. Ser, 10: $257-263$

Børsheim, K. Y. (1984). Clearance rates of bacteria-sized particles by freshwater ciliates, measured with monodisperse fluorescent latex beads. Oecologia (Berl.) 64: 286-288

Burney, C. M., Davis, P. G., Johnson, K. M., Sieburth, J. McN. (1981). Dependence of dissolved carbohydrate concentrations upon small scale nanoplankton and bacterioplankton distributions in the Western Sargasso Sea. Mar. Biol. 65: 289-296

Burney, C. M., Davis, P. G., Johnson, K. M., Sieburth, J. McN. (1982). Diel relationships of microbial trophic groups and in situ dissolved carbohydrate dynamics in the Caribbean Sea. Mar. Biol. 67: 311-322

Caron, D. A., Davis, P. G., Madin, L. P., Sieburth, J. McN. (1982). Heterotrophic bacteria and bacterivorous protozoa in oceanic macroaggregates. Science 218: 795-797

Chapman-Andersen, D., Nilsson, J. R. (1968). On vacuole formation in Tetrahymena pyriformis Gl. Compt. Rend. Trav. Lab. Carlsberg 36: 405-432

Cynar, F. J., Estep, K. W., Sieburth, J. McN. (1985a). The detection and characterization of bacteria-sized protists in 'protist-free' filtrates and their potential impact on experimental marine ecology. Microb. Ecol. 11: 281-288

Cynar, F. J., Sieracki, M. E., Sieburth, J. McN. (1985b). Estimating plankton populations with the Apple II. Bioscience 35: 652-655

Daggett, P.-M., Nerad, T. A. (1982). Axenic cultivation of Bodo edax and Bodo uncinatus and some observations on feeding rate in monoxenic culture. (Abstr.) J. Protozool. 29: 290-291

Davis, P. G. (1982). Bacterivorous flagellates in marine waters. Ph. D. thesis, Univ. of Rhode Island, Kingston

Davis, P. G., Sieburth, J. McN. (1982). Differentiation of phototrophic and heterotrophic nanoplankton populations in marine waters by epifluorescence microscopy. Annl. Inst. océanogr., Paris 58 (S): 249-260

Davis, P. G., Sieburth, J. McN. (1984). Estuarine and oceanic microflagellate predation of actively growing bacteria: estimation by frequency of dividing-divided bacteria. Mar. Ecol. Prog. Ser. 19: 237-246

Davis, P. G., Caron, D. A., Johnson, P. W., Sieburth, J. McN. (1985). Phototrophic and apochlorotic components of picoplankton and nanoplankton in the North Atlantic: geographic, vertical, seasonal and diel distributions. Mar. Ecol. Prog. Ser. 21: 15-26

Dubonsky, N. (1974). Selectivity of ingestion and digestion in the Chrysomonad flagellate Ochromonas malhamensis. J. Protozool. 21: 295-298

Fenchel, T. (1980). Suspension feeding in ciliated protozoa: Functional response and particle size selection. Microb. Ecol. 6: 1-11

Fenchel, T. (1982a). Ecology of heterotrophic microflagellates. I. Some important forms and their functional morphology. Mar. Ecol. Prog. Ser. 8: 211-223

Fenchel, T (1982b). Ecology of heterotrophic microflagellates. IV. Quantitative occurrence and importance as bacterial consumers. Mar Ecol. Prog. Ser. 9: 35-42

Fenchel, T. (1982c). Ecology of heterotrophic microflagellates. II. Bioenergetics and growth. Mar. Ecol. Prog. Ser. 8: 225-231

Fuhrman, J. A., McManus, G. B. (1984). Do bacteria-sized marine eukaryotes consume significant bacterial production? Science 224: 1257-1260

Goldman, J. C. (1984a). Conceptual role for microaggregates in pelagic waters. Bull. mar. Sci. 35; 462-476

Goldman, J. C. (1984b). Oceanic nutrient cycles. In: Fasham, M. J. (ed.) Flows of energy and materials in marine ecosystems. Theory and practice. Plenum, London, p. 137-170

Goldman, J. C., Caron, D. A., Andersen, O. K., Dennett, M. R. (1985). Nutrient cycling in a microflagellate food chain: I. Nitrogen dynamics. Mar. Ecol. Prog. Ser. 24: 231-242

Greissmann, K. (1914). Über marine Flagellaten. Arch. Protistenk. 32: 1-78

Güde, H. (1985). Influence of phagotrophic processes on the regeneration of nutrients in two-stage continuous culture systems. Microb. Ecol. 11: 193-204

Hamburger, K. (1965). The effect of adding nutrients to starved synchronous populations of Tetrahymena pyriformis at various stages of the cell cycle. In: Brogger, A. (ed.) Rep. 4th Scand. Congr Cell Res. Scand. Soc. Cell Biol., Oslo, p. 87

Haney, J. F. (1973). An in situ examination of the grazing activities of natural zooplankton communities. Arch. Hydrobiol. 72: 87-132

Hewes, C. D., Holm-Hansen, O. (1983). A method for recovering nanoplankton from filters for identification with the microscope: the filter-transfer-freeze (FTF) technique. Limnol. Oceanogr. $28: 389-394$

Hodgman, C. D., Weast, R, C., Sharkland, R. S., Selby, S. M. (1962). Handbook of chemistry and physics, 44th edn. CRC, Cleveland, p. 347

Hollibaugh, J. T., Fuhrman, J. A., Azam, F. (1980). Radioactive labeling of natural assemblages of bacterioplankton for use in trophic studies. Limnol. Oceanogr. 25: 172-181

James-Clark, H. (1868). On the spongiae ciliatae as infusoria 
flagellata; or observations on the structure, animality and relationship of Leucosolenia botryoides Bowerbank. Ann. Mag. Nat. Hist. 19: 13-18

Johnson, P. W., Sieburth, J. McN. (1979). Chroococcoid cyanobacteria in the sea: a ubiquitous and diverse phototrophic biomass. Limnol. Oceanogr. 24: 928-935

Johnson, P. W., Sieburth, J. McN. (1982). In-situ morphology and occurrence of eucaryotic phototrophs of bacterial size in the picoplankton of estuarine and oceanic waters. $J$. Phycol. 18: 318-327

Leadbeater, B. S. C. (1985). Order 1. Choanoflagellida Kent, 1880. In: Lee, J. J., Hutner, S. H., Bovee, E. C. (ed.) An illustrated guide to the Protozoa. Soc. Protozool., Lawrence, Kansas, p. 106-116

Lessard, E. J., Swift, E. (1985). Species-specific grazing rates of heterotrophic dinoflagellates in oceanic waters, measured with a dual-label radioisotope technique. Mar. Biol. 87: 289-296

Lighthill, J. (1976). Flagellar hydrodynamics. SIAM (Soc. Indus. Appl. Math.) Rev. 18: 161-230

Linley, E. A. S., Newell, R. C., Lucas, M. I. (1983). Quantitative relationships between phytoplankton, bacteria and heterotrophic microflagellates in shelf waters. Mar Ecol. Prog. Ser. 12: 77-89

McManus, G. B., Fuhrman, J. A. (1986). Bacterivory in seawater studied with the use of inert fluorescent particles. Limnol. Oceanogr. 31: 420-426

Morris, I. (1966). Inhibition of protein synthesis by cycloheximide (actidione) in Chlorella. Nature, Lond. 211: $1190-1192$

Mueller, M., Rohlich, P., Toro, I. (1965). Studies on feeding and digestion in protozoa. VII. Ingestion of polystyrene latex particles and its early effect on acid phosphatase in Paramecium multimicronucleatum and Tetrahymena pyriformis. J. Protozool. 12: 27-34

Nachtwey, D. S., Dickinson, W. J. (1967). Actinomycin D: Blockage of cell division of synchronized Tetrahymena pyriformis. Expl Cell Res. 47: 581-595

Newell, S. Y., Sherr, B. F., Sherr, E. B., Fallon, R. D. (1983). Bacterial response to presence of eukaryote inhibitors in water from a coastal marine environment. Mar. environ. Res. 10: 147-157

Pace, M. L. (1986). Problems in measuring protozoan grazing with fluorescent microspheres. Abstr. Amer Soc. Limnol. Oceanogr. 50th Mtg., Am. Soc. Limnol. Oceanogr., Lawrence, Kansas, p. 96

Peterson, B. J., Hobbie, J. E., Haney, J. F. (1978). Daphnia grazing on natural bacteria. Limnol. Oceanogr. 23: 1039-1044

Porter, K. G., Feig, Y. S. (1980). The use of DAPI for identifying and counting aquatic microflora. Limnol. Oceanogr. 25: $943-948$

Sanders, R. W., Porter, K. G. (in press). Use of metabolic inhibitors to estimate protozooplankton grazing and bacterial production in a monomictic eutrophic lake with an anaerobic hypolimnion. Appl. environ. Microbiol.

Sherr, B. F., Sherr, E. B. (1984). Role of heterotrophic protozoa in carbon and energy flow in aquatic ecosystems. In: Klug. M. J., Reddy, C. A. (ed.) Current perspectives in microbial ecology. ASM, Washington D.C., p. 412-423

Sherr, B. F., Sherr, E. B., Berman, T. (1982). Decomposition of organic detritus: A selective role for microflagellate protozoa. Limnol. Oceanogr. 27: 765-769

Sherr, B. F., Sherr, E. B., Berman, T (1983). Growth, grazing and ammonia excretion rates of a heterotrophic microflagellate fed with four species of bacteria. Appl. environ. Microbiol. 45: 1196-1201

Sherr, B. F., Sherr, E. B., Newell, S. Y. (1984). Abundance and productivity of heterotrophic nanoplankton in Georgia coastal waters. J. Plankton Res. 6: 195-202

Sibbald, M. J., Albright, L. J. (1986). The chemosensory response of a heterotrophic microflagellate to its bacterial prey. Abstr. Amer. Soc. Limnol. Oceanogr. 50th Mtg., Am. Soc. Limnol. Oceanogr., Lawrence, Kansas, p. 118

Sieburth, J. McN. (1976). Bacterial substrates and productivity in marine ecosystems. Ann. Rev. Ecol. Syst. 7: 259-285

Sieburth, J. McN. (1979). Sea microbes. Oxford Unitersity Press, New York

Sieburth, J. McN., Smetacek, V., Lenz, J. (1978). Pelagic ecosystem structure: Heterotrophic compartments of the plankton and their relationship to plankton size fractions. Limnol. Oceanogr. 23: 1256-1263

Sieburth, J. MCN., Davis, P. G. (1982). The role of heterotrophic nanoplankton in the grazing and nurturing of planktonic bacteria in the Sargasso and Caribbean Seas. Annls. Inst. océanogr. Paris 58 (S): 285-296

Sieracki, M. E., Johnson, P. W., Sieburth, J. McN. (1985). Detection, enumeration, and sizing of planktonic bacteria by image-analyzed epifluorescence microscopy. Appl. environ. Microbiol. 49: 799-810

Silver, M. W., Shanks, A. L., Trent, J. D. (1978). Marine snow: Microplankton habitat and source of small-scale patchiness in pelagic populations. Science 201: 371-373

Snedecor, G. W. Cochran, W. G. (1980). Statistical methods, 7 th edn. Iowa State University, Ames. p. 130-133

Taylor, G. T., Iturriaga, R, Sullivan, C. W. (1985). Interactions of bactivorous grazers and heterotrophic bacteria with dissolved organic matter. Mar. Ecol. Prog. Ser. 23: 129-141

Watson, S. W., Notivsky, T. J, Quinby, H. L., Valois, F. W (1977). Determination of bacterial number and biomass in the marine environment. Appl. environ. Microbiol. 33: 940-946

Wright, R. T., Coffin, R. B. (1984). Measuring microzooplankton grazing on planktonic marine bacteria by its impact on bactenal production. Microb. Ecol. 10: 137-149 